\title{
СПЕЦИАЛИЗИРОВАННЫЕ ОРГАНИЗАЦИИ РАЗВИТИЯ ИННОВАЦИОННЫХ ТЕРРИТОРИАЛЬНО-ПРОИЗВОДСТВЕННЫХ КЛАСТЕРОВ В ЭКОНОМИКЕ КАБАРДИНО-БАЛКАРСКОЙ РЕСПУБЛИКИ НА ПРИМЕРЕ АГРОПРОМЫШЛЕННОГО КЛАСТЕРА
}

\author{
Шидов А.Х., \\ Гедгафова И.Ю., \\ Казиева Б.В. \\ ФГБОУ ВО «КБГУ», г. Нальчик, Россия
}

Кластеры являются инновачионной формой диверсификаџии и развития региональной экономики. $B$ статье дается определение кластерной диверсификации и предлагается в интересах реализации кластерных проектов в Кабардино-Балкарской республике создать специализированные организации развития инновачионных территориально-производственных кластеров и закрепить это правительственным постановлением.

Ключевые слова: кластер, кластерная диверсификация, специализированные организации развития, экономическое развитие, регион.

Приоритетное влияние на развитие действующей в КабардиноБалкарской республике системы рыночных отношений должна оказывать кластерная диверсификация, представляющая собой интеграцию ведущих научно-исследовательских и образовательных организаций, хозяйствующих субъектов, институтов развития и органов власти, обеспечивающих методическое, организационное, экспертно-аналитическое и информационное развитие инновационных территориально-производственных кластеров, которые способствуют повышению эффективности промышленного производства и росту конкурентоспособности экономики республики в целом [1].

Опыт российских регионов свидетельствует о том, что кластерная диверсификация превратилась в ключевой инструмент их экономического развития. В этой связи регионы России, вставшие на путь интенсивного инновационного развития, начали создавать новую модель организации экономики - не отраслевую, а территориально-отраслевую, или кластерную, которая закономерно приводит к формированию инновационных территориально-производственных кластеров.

Кластерный анализ российских регионов показал, что политика кластеризации экономики Кабардино-Балкарской республики может быть успешна только в том случае, когда будут учитываться все ее ключевые факторы: субъектами;

a) расширение кооперационных связей между хозяйствующими 
b) достраивание производственных цепочек создания стоимости;

c) развитие импортозамещающих компетенций и производств;

d) повышение инвестиционной привлекательности конкурентоспособности компаний и районов их базирования.

Кроме того, в рамках Кабардино-Балкарской республики следует создать специализированные организации развития инновационных территориальнопроизводственных кластеров, целью деятельности которых является создание условий для эффективного взаимодействия организаций - участников инновационных территориально-производственных кластеров (учреждений образования и науки, некоммерческих и общественных организаций, органов государственной власти и местного самоуправления, инвесторов).

На примере агропромышленного кластера рассмотрим основные виды деятельности специализированной организации развития инновационного территориально-производственного кластера:

1. Разработка и содействие реализации проектов его развития, выполняемых совместно двумя и более организациями - участниками агропромышленного кластера.

2. Организация подготовки, переподготовки, повышения квалификации и стажировок кадров, предоставления консультационных услуг в интересах организаций - участников агропромышленного кластера.

3. Оказание содействия предприятиям и организациям - участникам инновационного агропромышленного кластера в выводе на рынок новых продуктов (услуг), развитию кооперации организаций - участников инновационного агропромышленного кластера в научно-технической сфере, в том числе с зарубежными организациями.

4. Организация выставочно-ярмарочных и коммуникативных (форумы, конференции, семинары, круглые столы) мероприятий в сфере интересов организаций - участников инновационного агропромышленного кластера, а также их участия в выставочно-ярмарочных и коммуникативных (форумы, конференции, семинары, круглые столы) мероприятиях, проводимых за рубежом.

Кроме того, специализированная организация развития инновационного агропромышленного кластера должна осуществлять:

a) оказание консультационных услуг его предприятиям и организациям - участникам по направлениям реализации программы развития инновационного агропромышленного кластера;

b) организацию предоставления услуг его предприятиям и организациям - участникам в части правового обеспечения, маркетинга, рекламы;

c) проведение информационных кампаний в средствах массовой информации по освещению деятельности инновационного агропромышленного кластера и перспектив его развития;

d) проведение маркетинговых исследований на различных рынках, связанных с продвижением продукции инновационного агропромышленного кластера. 
Все вышеперечисленные требования к специализированной организации развития инновационного агропромышленного кластера следует закрепить в Постановлении Правительства Кабардино-Балкарской республики «О специализированной организации развития инновационного территориальнопроизводственного кластера». Его можно разработать, взяв за основу Постановление Правительства РФ от 31 июля 2015 г. № 779 «О промышленных кластерах и специализированных организациях промышленных кластеров» [2].

Исследование выполнено при финансовой поддержке РФФИ в рамках научного проекта №18-010-00947.

\section{Список литературы}

1. Гранкина Виктория Леонидовна. Развитие кластерной диверсификации в системе современных рыночных отношений: диссертация ... кандидата Экономических наук: 08.00.01 / Гранкина Виктория Леонидовна; [Место защиты: Научно-исследовательский институт труда и социального страхования]. - Москва, 2016.

2. О промышленных кластерах и специализированных организациях промышленных кластеров. Постановление Правительства РФ от 31 июля 2015 г. № 779 [Электронный ресурс]. - Режим доступа: http://www.consultant.ru/document/cons_doc_LAW_183798/. 